\title{
Transcriptional expression of three putative pathogenesis-related proteins in leaves of rubber tree (Hevea brasiliensis) inoculated with Neofusicoccum ribis
}

\author{
A. I. C. Nyaka Ngobisa ${ }^{1,4 *}$, Godswill Ntsomboh-Ntsefong ${ }^{2,5}$, Wong Mui Yun ${ }^{1,3}$, M. Z. Dzarifah ${ }^{1}$, P. A. Owona Ndongo ${ }^{4}$ \\ ${ }^{1}$ Department of Plant Protection, Faculty of Agriculture, Universiti Putra Malaysia, 43400 UPM Serdang, Selangor, Malaysia. ${ }^{2}$ Institute of Agricultural \\ Research for Development (IRAD), CEREPAH La Dibamba, BP 243 Douala, Cameroon. ${ }^{3}$ Laboratory of Plantation Crops, Institute of Tropical Agriculture, \\ Universiti Putra Malaysia, 43400 UPM Serdang, Selangor, Malaysia. ${ }^{4}$ Institute of Agricultural Research for Development (IRAD), Ekona Regional Centre, \\ Latex (LPP) Plant Program, PMB 25 Buea, Cameroon. ${ }^{5}$ CNRS, Membrane Biogenesis Laboratory, UMR5200, 33140 Villenave d'Ornon, France.
}

\section{ARTICLE INFO}

Article history:

Received on: 30/12/2015

Revised on: 10/02/2016

Accepted on: 25/03/2016

Available online: 21/04/2016

Key words:

Gene expression, RT-PCR,

Neofusicoccum ribis,

Pathogenesis-related protein

\begin{abstract}
Pathogenesis related-proteins (PR-proteins) and enzymes are important tools for understanding the molecular markers of plant response to external factors. In this study, semi-quantitative reverse transcription polymerase chain reaction (RT-PCR) was optimized to detect the expressions of two PR-proteins and one enzyme extracted from the leaf RNA of two rubber clones (PB 350 and RRIM 2002) at four-period intervals. The expression patterns of enzymes $\beta$-1,3-glucanase (Glu), chitinase (Chit), and phenylalanine ammonia lyase (PAL) in the leaf tissues of the clones RRIM 2002 and PB 350 to Neofusicoccum ribis were expressed by up and down regulations and varied with time. The trial inoculation indicated that the gene expressions were significantly higher in tolerant clones (RRIM 2002) than in the susceptible clones (PB 350). Gene expression analysis of the biomarkers revealed that the earlier detection markers in infections occurred within 5-10 days post infection and showed significant correlation with disease development, ranging from $1.67-3 \%$ in the RRIM 2002 clone and approximately $8.33 \%$ in the PB 350 clone. This is the first study on the infection and up-regulation of gene expression in rubber leaves infected with $N$. ribis. This study showed the importance of exploring the SK10 isolate as an indicator of infection ability and positive fungal-host interaction.
\end{abstract}

\section{INTRODUCTION}

The leaves of most plants have lesser numbers of Botryosphaeriaceae endophytes or parasites when compared with other plant tissues such as the roots and stems 1. In general, Botryosphaeriaceae which are commonly endophytes, reside within the tissues of several woody plants, including gymnosperms and angiosperms, without causing any symptoms 2. Adequate leaf colonization by pathogens and establishment within plants are critical in the selection of foliar endophytes or parasites for disease control. Conversely, insufficient colonization may lead to the failure of leaf disease diagnosis 3 .

\footnotetext{
* Corresponding Author NyakaNgobisa A. I. C., ' Department of Plant Protection, Faculty of Agriculture, Universiti Putra Malaysia, 43400 UPM Serdang, Selangor, Malaysia. ${ }^{4}$ Institute of Agricultural Research for Development (IRAD), Ekona Regional Centre, Latex (LPP) Plant Program, PMB 25 Buea, Cameroon.Email: boulnyaka@yahoo.com
}

Studies have been conducted on the interactions between plants and members of the Botryosphaeriaceae, including the genus Neofusicoccum, by inoculating plants grown under sterile conditions followed by microscopic analyses 4 . The use of reporter genes and chitinase (Chit), $\beta-1,3$-glucanase ( $\beta-1,3-\mathrm{Glu})$ that hydrolyses $\beta-1,4$-glycosidic bonds in chitin 5 and catalyzes the cleavage of $\beta$-1,3-glycosidic bonds in $\beta$-1,3-glucan 6 , and an enzyme phenylalanine ammonia lyase (PAL) that is involved in various metabolic changes in plants 7 have facilitated the study on leaf colonization and fungal action in their hosts in rubber plants 8.Certain plant developmental stages are particularly vulnerable to infection and require additional protection to aid in their productive cycle 24 . Chit, $\beta-$ Glu, and PAL genes, which were previously selected as candidate markers, have proven to be reliable markers for induced defense responses to some rubber leaf diseases 8 . PR proteins have been detected in response to leaf infection caused by Corynespora cassiicola 8, Colletotrichum gloeosporioides, Mycrocyclus ulei [9], and Phytophthora palmivora 10. 
Neofusicoccum ribis is a fungus associated with leaf blight disease in rubber plants in Malaysia 11. However, the mechanism by which the $N$. ribis isolate, SK10, associates itself with the host plant is yet to be ascertained. Thus, studies are required to determine the ability of this fungus to infect leaves as well as to identify its possible role in the induction of resistance in rubber plants or in rubber leaves. This study investigated the leaf colonization pattern and studied the related responses induced by the $N$. ribis (isolate SK10) in rubber, with a focus on the molecular mechanisms of infection with regard to the role of Chit, Glu, and the enzyme PAL.

\section{MATERIALS AND METHODS}

\subsection{Biological materials and disease scoring}

Isolate SK10 (ICMP 20078) (ICMP: International Collection of Microorganisms from Plants, New Zealand), showing $N$. ribis conidia (Fig. 1a) was selected to inoculate leaves of two rubber $(H$. brasiliensis) clones of RRIM 2002 and PB 350. Fully expanded leaflets (limp green stage) from plants that had been raised in polybags were inoculated by spraying $50 \mathrm{ml}$ of a conidia suspension $\left(1 \times 10^{5}\right.$ conidia / ml) of $N$. ribis. The control treatment was performed simultaneously using sterile distilled water. Disease scoring was carried out with three replications following the method described in 11 and mean infection scores were calculated. After spraying, all the plants (treated and control) were covered with transparent polythene bags to maintain the required humidity and the bags were removed a day after. Three leaves were harvested from each inoculated plant at regular intervals (1, 5, 10 and 15 days), dipped into liquid nitrogen and stored at $-80^{\circ} \mathrm{C}$ until needed for RNA extraction.

\subsection{Semi-quantitative reverse transcription $P C R$ analysis}

Total RNA were extracted from treated and untreated leaf tissues from the best replication trial showing symptoms of blight, using the modified sodium dodecyl sulfate (SDS) method 25 on leaf tissue harvested at regular intervals (days after pathogen inoculation), for the study of the natural level of expression.

The purity of the RNA was detected using a spectrophotometer (Thermoscientific, USA) at different wavelengths (230, 260 and $280 \mathrm{~nm}$ ) and its integrity examined using 1\% agarose gel electrophoresis. The total RNA was treated with DNase I (Fermentas, UAB, Lithuania) and the concentration was determined using Nanodrop 2000cc (Thermoscientific, USA). The rest of the RNA samples were stored at $-80^{\circ} \mathrm{C}$ for further use. Expression pattern of $\beta$-1,3-glucanase, Chitinase and Phenylalamnie ammoniase lyase (Chit and Glu and PAL) genes were analyzed by Reverse Transcriptase Polymerase Chain reaction (RT-PCR) 14.

First-strand cDNA was synthesized following the manufacturer's protocol using RevertAid ${ }^{\mathrm{TM}}$ First strand cDNA synthesis kit (Fermentas, UAB, Lithuania) from total RNA $(1 \mu \mathrm{g})$ an olig $(\mathrm{dT})^{18}$ primer. PCR amplification of pathogenesis-related genes (Chit and Glu and PAL) was performed using 2X PCR Master Mix (iNTRON biotechnology, Korea).

Using $100 \mathrm{ng}$ total RNA as template, reverse transcription was performed using PCR and several primers (Table. 1) in a PCR mix containing PCR Master mix, $1 \mu \mathrm{M}$ primer oligonucleotides and nuclease-free water. Each $20 \mu$ PCR mixture contained $2 \mathrm{X}$ PCR buffer [2.5 U of i-Taq TM DNA polymerase (5 U/ul 2.5 Mm each of dNTPs, Reaction buffer (10X), and gel Loading].
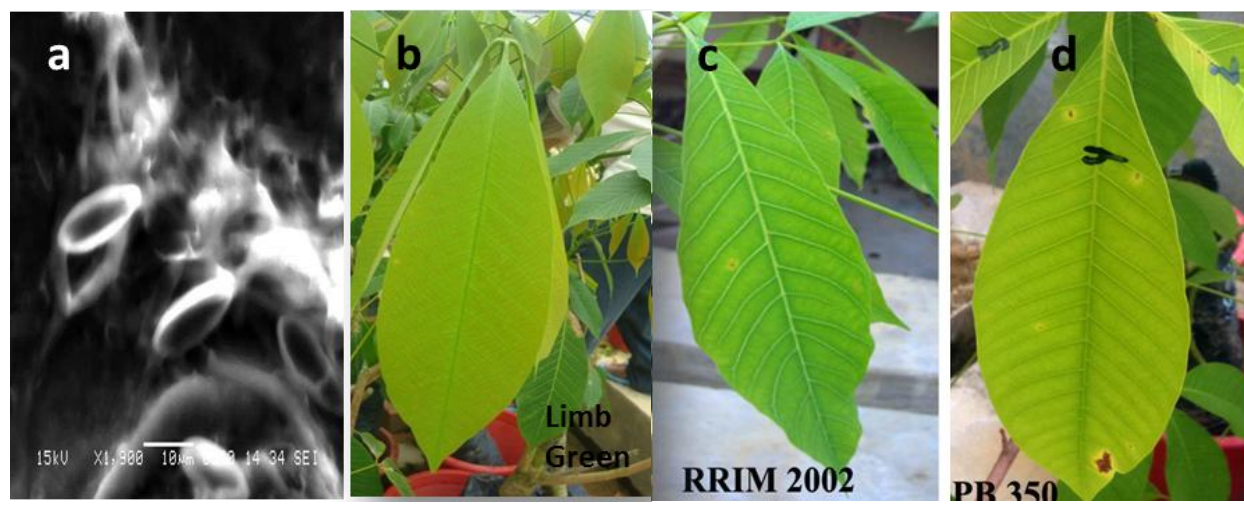

Fig. 1: Images showing scanning electron microscopic of Neofusicoccum ribis spore and the responses of seedlings of different rubber clones inoculated with the isolate (SK10) after 15 days.

Table 1: Primers used for RT-PCR.

\begin{tabular}{|c|c|c|c|}
\hline Genes & & Primer Sequence $\left(5^{\prime} \rightarrow 3^{\prime}\right)$ & Product size (bp) \\
\hline beta-1,3 glucanase & $\begin{array}{l}\text { Forward } \\
\text { Reverse }\end{array}$ & $\begin{array}{l}\text { GCTATGGAATGCAAGGCAAC } \\
\text { TTGGCCGTTTATCAGGAAAG }\end{array}$ & 910 \\
\hline Chitinase & $\begin{array}{l}\text { Forward } \\
\text { Reverse }\end{array}$ & $\begin{array}{l}\text { AAA TCT TCT TCC CGT CCC TTA G } \\
\text { CTT GCC TTG CTT GCT ATA TGC }\end{array}$ & 85 \\
\hline Phenylalanine ammonia lyase & $\begin{array}{l}\text { Forward } \\
\text { Reverse }\end{array}$ & $\begin{array}{l}\text { TGGAGCACATTTAGATGGT } \\
\text { CGCTTTGTACATGGCTAGTG }\end{array}$ & 486 \\
\hline Glyceraldehyde phosphate dehydrogenase & $\begin{array}{l}\text { Forward } \\
\text { Reverse }\end{array}$ & $\begin{array}{l}\text { GCC TGT GAT AGT CTT CGG TGT TAG } \\
\text { GCA GCC TTA TCC TTG TCA TGT AAC }\end{array}$ & 190 \\
\hline
\end{tabular}

Source of primer sequences: Glu, Chit and PAL 14; GAPDH 23. 
followed by 30 cycles at denaturing temperature $\left(98{ }^{\circ} \mathrm{C}\right.$ for 10 sec), annealing $\left(50^{\circ} \mathrm{C}\right.$ for $\left.30 \mathrm{~min}\right)$, extension $\left(68^{\circ} \mathrm{C}\right.$ for $\left.1 \mathrm{~min}\right)$ and final extension $\left(72{ }^{\circ} \mathrm{C}\right.$ for $\left.7 \mathrm{~min}\right)$. PAL and GAPDH genes amplification followed the same reaction cycles of Chit and Glugenes with denaturing temperature $\left(95^{\circ} \mathrm{C}\right.$ for $\left.1 \mathrm{~min}\right)$, annealing $\left(60{ }^{\circ} \mathrm{C}\right.$ for $\left.1 \mathrm{~min}\right)$, extension $\left(72{ }^{\circ} \mathrm{C}\right.$ for $2 \mathrm{~min}$ ) and final extension (72 ${ }^{\circ} \mathrm{C}$ for $10 \mathrm{~min}$ ). Glyceraldehyde phosphate dehydrogenase (GAPDH) gene was used as an internal control 23.

\section{RESULTS AND DISCUSSION}

The necrosis spots developed due to hypersensitive responses induced by the pathogen were similar to Neofusicoccum leaf blight symptoms (Fig. 1cd) on detached inoculated leaves 11 . A shift or change in susceptibility was probably influenced by the prevailing weather conditions such as temperature, humidity, and inoculum load on the rubber leaf tissue. However, increases in the disease intensity (DI) percentage ranged from $1.67-3 \%$ in the RRM 2002 clone and up to $8.33 \%$ in the PB 350 clone (Fig. 2). The findings demonstrate that some Botryosphaeriaceae species interact with their hosts in a similar way as the endophytes in the branches, leaves, and fruits and become pathogenic when the host is under stress 12 .

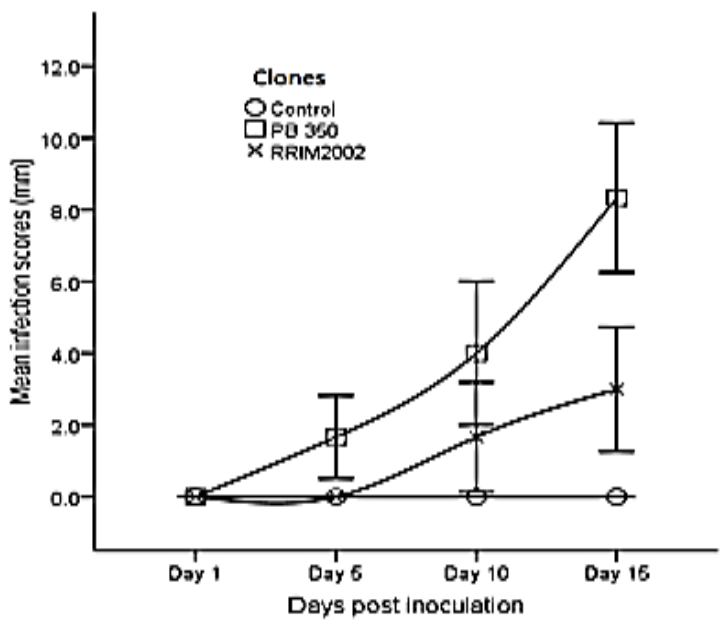

Fig. 2: Development of infection in rubber leaves after inoculation with Neofusicoccum ribis isolate, SK10. The bars represent the standard deviation of the mean infection scores of 3 replicates, which are significantly different $(\mathrm{P}<$ $0.05)$. suggested that structural and physiological defense mechanisms against $N$. ribis in each clone developed gradually until 15 days after inoculation (DAI). The rubber leaves at the limp green stage are free of lignin, may be because of PAL activity, which is associated with the biosynthesis of toxic metabolites such as phytoalexin, phenols, lignins, and salicylic acid in plant defense pathways 7 . This demonstrated the role played by PAL enzymes in disease development on resistance in plant tissue. Interestingly, PAL expression was maintained or elevated in resistant plants for a longer period than in susceptible plants, although both plants initially showed elevated PAL expressions 13.

The expressions of the genes encoding $\beta-1-3-$ Glu, Chit, and PAL in the two rubber clones in response to inoculation with the $N$. ribis isolate, SK10 was evaluated using semi-quantitative reverse-transcription polymerase chain reaction (RT-PCR) 14. Constant low signal levels were recorded for all the genes at all time intervals when using distilled water as the control, whereas after $N$. ribis inoculation, the gene expression level was higher in RRIM 2002 than in PB 350 at all harvest periods (Fig. 3).

In the resistant clone RRIM 2002, expression of $\beta-1,3-$ Glu and Chit started early at 1 DAI. In RRIM 2002, $\beta$-1,3-Glu was up regulated at $1,5,10$, and $15 \mathrm{DAI}$, while Chit was up regulated at 1, $10 \mathrm{DAI}$ and PAL at $15 \mathrm{DAI}$. However, the timing and magnitude of induction of the $H$. brasiliensis clones infected with Phytophthora meadii showed an exponential increase in $\beta$-glucan transcripts at $48 \mathrm{~h}$ after inoculation, and this induction was higher and more prolonged in tolerant clones than in the susceptible clone 14. The gene expressions could be related to the early detection at $5 \mathrm{DAI}$ and to disease development observed during pathogenicity in detached rubber leaves. The authors of 15 and 16 showed the involvement of chitinase genes in the rice defense response against Pyricularia grisea, and found that phenylalanine ammonia lyases and peroxidases genes were up-regulated after 36 and $18 \mathrm{~h}$, respectively, for 0.5 and $10 \mu \mathrm{mol}$ manganese fungal in the absence of silicon. PAL gene expression is induced under stressful conditions like UV light irradiation, ozone exposure, boron treatment, and pathogen attack 17 . In the susceptible clone, PB 350 , the $\beta-1,3-$ Glu expression was down regulated at 15 DAI, while Chit expression was delayed and then upregulated at 10 and 15 DAI. Upregulation of PAL was initiated at 5 DAI. A few studies showed the induction of $\beta-1,3-$ Glu activity in response

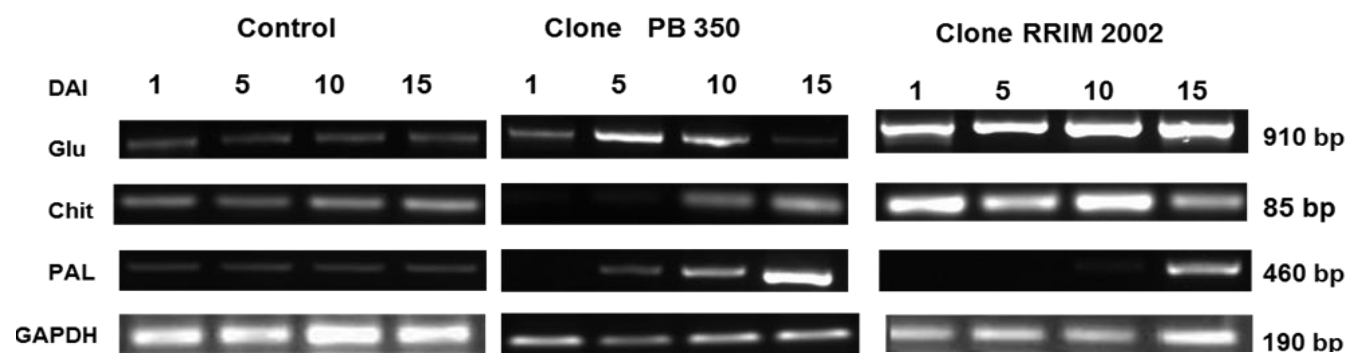

Fig. 3: Semi-quantitative reverse transcription polymerase chain reaction analysis of $\beta$-1,3-glucanase (Glu) and chitinase (Chit) genes and PAL expression in response to PB 350 and RRIM 2002 leaf inoculation with the Neofusicoccum ribis isolate, SK10 (JX035744) and sterile distilled water (control), 15 days after 1 inoculation. The GAPDH was used as the control for normalizing mRNA quantity. 
genotype) could be associated with the level of PR-proteins and PAL gene expressions in rubber leaf samples visualized as a fluorescent band 7. We suppose that clonal susceptibility to $N$. ribis in terms of the gene expression pattern was evident in the $\mathrm{PB}$ clones than in the RRIM series clones. PB 350 is a promising clone that shows vigorous growth and is susceptible to Neofusicoccum infection. The common lineage (RRIM $600 \times$ PB 325 ) could account for their predisposition to the disease. In addition, although RRIM 600 shows adaptation under specific environments 20 , it is also susceptibility to several leaf diseases such as Corynespora leaf fall, Phytophthora leaf fall, and Oidium leaf fall 21. Gene expression in the leaf tissue inoculated with distilled water could indicate that these genes are constitutive and expressed in leaf tissues. This indicated that defense gene activation signals were recognized by the host plant long before host cell infection by the pathogen was established 22. Moreover, PAL activity in the control leaf could be associated with inoculated leaf stress. In both instances, the leaves can be considered to be under stress (e.g., infected or uninfected).

Although in clone PB 350, $\beta-1,3-$ Glu was downregulated at $10 \mathrm{DAI}$, the expressions of both genes increased constantly as the number of days increased and was markedly high. This could be related to the endophytic and parasitic stage of $N$. ribis in asymptomatic rubber tissue at $10 \mathrm{DAI}$, which ranged from approximately $1.53 \%$ to $2.8 \%$ DI. However, to our knowledge, no studies have shown the biochemical mechanisms of the resistance of rubber plants against $N$. ribis potentiated by the genes related to DI. Our study findings indicate that the SK10 isolate could potentially induce systemic resistance in rubber. However, further studies are warranted for the validation of this strain in stimulating host defense.

\section{ACKNOWLEDGEMENTS}

We thank the Universiti Putra Malaysia (UPM) as well as the Plant Protection Department at the Faculty of Agriculture UPM, for logistical support. We are grateful to Dr Mfeugue Virginie at IRAD Cameroon and Dr Beyegue Djonko Honore at the University of Dschang Cameroon for their assistance and guidance.

\section{REFERENCES}

1. Gazis R and Chaverri P. Diversity of fungal endophytes in leaves and stems of wild rubber trees (Hevea brasiliensis) in Peru. Fungal Ecology. 2010; 3 (3): 240-254.

2. Slippers B and Wingfield MJ. Botyosphaeriaceae as endophytes and latent pathogens of woody plants: diversity, ecology and impact. Fungal Biology Reviews. 2007; (21): 90-106.

3. Narayanasamy P. Microbial Plant Pathogens-Detection and Disease Diagnosis. Fungal Pathogens. 2010; 1: 20-26.

4. Begoude BAD, Slippers B, Wingfield MJ and Roux J. Identity and pathogenicity of botryosphaeriaceous fungi on Terminalia species in Cameroon. Forest Pathology. 2011; 41 (4): 281-292.

5. Sekeli R, Tan Yik Wan Y, Kulaveerasingam H, Napis S, Hee TS. The Isolation and Expression Analysis of a Class I Chitinase from Developing Winged Bean Seed (Psophocarpus tetragonolubus). Asia
Pacific Journal of Molecular Biology and Biotechnology. 2003; 11 (2):63-69.

6. Simmons R. The physiology and molecular biology of plant $\beta-1,3-$ glucanase and 1, 3: 1, 4- $\beta$-D- glucanases. Critical Reviews in Plant Sciences. 1994; 13:325.-325

7. Wen P-F, Chen J-Y, Kong W-F, Pan Q-H, Wan S-B and Huang WD. Salicylic acid induced the expression of phenylalanine ammonialyase gene in grape berry. Plant Science. 2005; 169: 928-934.

8. Philip S, Joseph A, Kumar A, Jacob CK and Kothandaraman R. Detection of $\beta-1,3$ - glucanase isoforms against Corynespora leaf disease of rubber (Hevea brasiliensis). Indian Journal of Natural Rubber Research. 2001; 14(1): 1-6.

9. Garcia et al. 1995 Garcia D, Cazaux E, Rivano F, AuzacJd. Chemical and structural barriers to Microcyclus ulei, the agent of South American leaf blight. Hevea spp. European Journal of Forest Pathology. 1995; 25: 282-292.

10. Thanseem A and Thulaseedharan A. Optimization of RQRT-PCR protocols to measure $\beta-1,3$-glucanase mRNA levels in infected tissues of rubber tree (Hevea brasiliensis). Indian Journal of Experimental Biology. 2006; 44: 492-498.

11. NyakaNgobisa AIC, Zainal Abidin MA, Wong MY and Wan Noordin MWD. Neofusicoccum ribis Associated with Leaf Blight on Rubber (Hevea brasiliensis) in Peninsular Malaysia. Plant Pathology Journal. 2013; 29 (1): 10-16.

12. Smith H, Wingfield MJ, Crous PW and Coutinho TA. Sphaeropsis sapinea and Botryosphaeria dothidea endophytes in Pinus spp. and Eucalyptus spp. in South Africa. South Africa Journal of Botany. 1996; 62: 86-88.

13. Lee SW, Nazar RN, Powell DA and Robb J. Reduced PAL gene suppression in Verticillium-infected resistant tomatoes. Plant Molecular Biology. 1992; 18:345-352.

14. Thanseem A J. and Thulaseedharan A. Induction and differential expression of $\beta$-1, 3-glucanase mRNAase in tolerant and susceptible Hevea clones in response to infection by Phytophthora meadii. Tree Physiology. 2005; 25: 1361-1368.

15. Brunings AM, Datnoff LE, Ma JF, Mitani N, Nagamura Y, Rathinasabapathi B and Kirst M. Differential gene expression of rice in response to silicon and rice blast fungus Magnaportheoryzae. Annals of Applied Biology. 2009; 155(2): 161-170.

16. Matheus RS, Pereira CS, Rodrigues FA, Luiz Antônio Zanão J, Renildes LFF and Oliveira MGA. Silicon and manganese on the activity of enzymes involved in rice resistance against brown spot. Tropical Plant Pathology. 2012; 37(5): 339-345.

17. Biagioni M, Nali C, Heimler D and Lorenzini G. PAL activity and differential ozone sensitivity in tobacco, bean and poplar. Journal of Phytopathology. 1997; 145 (11-12): 533-539.

18. Ignatius SMJ, Chopra RK and Muthukrishnan S. Effects of fungal infection and wounding on the expression of chitinases and $\beta-1,3-$ glucanases in near-isogenic lines of barley. Physiology Plant. 1994; 90 (3): 584-592.

19. Krishnaveni S, Muthukrishnan S, Liang GH, Wilde G and Manickam A. Induction of chitinases and $\beta$-1,3-glucanases in resistant and susceptible cultivars of sorghum in response to insect attack, fungal infection and wounding. Plant Science. 1999; 144:9-16.

20. Priyadarshan PM. Contributions of weather variables for specific adaptation of rubber tree (Hevea brasiliensis Muell. - Arg) clones. Genetics and Molecular Biology. 2003; 26 (4): 435-440.

21. Tan AM, Loo TP, Vadivel G, Bachik MR and Yoon KK. Survey of major leaf diseases of rubber in Peninsular Malaysia. Planters Bulletin. 1992; 211: 51-62. 
22. Munch-Garthoff S, Neuhaus JM, Boller T, Kemmerling B and Kogel $\mathrm{KH}$. Expression of beta-1, 3-glucanase and chitinase in healthy, stemrust-affected and elicitor-treated near-isogenic wheat lines showing Sr5-or Sr-24- specified race-specific rust resistance. Planta. 1997; 201: 235-244.

23. Sathik MMB, KuruvillaL, ThomasM, Luke LP, Satheesh PR, Annamalainathan and Jacob J. Quantitative expression analysis of stress responsive genes under cold stress in Hevea brasiliensis. Rubber Science. 2012; 25(2):199-213.

24. Lotan $\mathrm{T}$, Ori $\mathrm{N}$ and Fluhr R. Pathogenesis-related proteins are developmentally regulated in tobacco flowers. Plant Cell. 1989; 1 (9): 881-887.
25. Yu D, Tang H, Zhang Y, Du Z, Yu H and Chen Q. Comparison and Improvement of Different Methods of RNA Isolation from Strawberry (Fragria X ananassa). Journal of Agricultural Science. 2012; 4 (6): 51-56.

\section{How to cite this article:}

Nyaka Ngobisa AIC, Ntsomboh-Ntsefong G, Wong MY, Dzarifah MZ, Owona Ndongo PA. Transcriptional expression of three putative pathogenesis-related proteins in leaves of rubber tree (Hevea brasiliensis) inoculated with Neofusicoccum ribis. J App Biol Biotech. 2016; 4 (02): 011-015. DOI: 10.7324/JABB.2016.40202 